\title{
The Beginnings of Modern Belarus: Identity, Nation, and Politics in a European Borderland
}

\section{Annual London Lecture on Belarusian Studies}

\author{
BY \\ PER ANDERS RUDLING*
}

One of the reasons I became interested in Belarus was the lack of research on the country. I was intrigued by the fact that there was a European country with a population larger than my native Sweden, larger than the three Baltic republics combined, larger than Austria, roughly as big as Norway and Denmark combined - on which there was very little research, and the body of literature in English consisted of a handful of books. In the past ten or so years, there has been a virtual explosion in literature on Belarus. Those of us who are working on matters Belarusian sense this increase in interest very clearly. Last semester, I was asked to teach a course on Belarusian history at Lund University, and this semester I was invited to teach Belarusian history at the University of Vienna. That western European universities offer courses dedicated exclusively to Belarusian history is something new.

So a lot of things are happening and I feel honoured to be invited by the Ostrogorski Centre and University College London to say a few words about my recent book. I will organise this lecture as a musing on the beginnings of modern Belarusian nationalism and the first attempts at establishing Belarusian statehood. It is a complex, contradictory story, culminating in no less than six declarations of statehood between 1917 and 1920.

\section{Belarusian Nationalism}

Before I get started, perhaps a short disclaimer regarding terminology may be in order. The term nationalism has been used to describe a number of ideas, currents and groups. For the purpose of this lecture, I use the term nationalism in the broadest possible sense: the articulation of a political agenda in the name of one particular imagined community with the intention of establishing a nation-state.

* Per Anders Rudling is Associate Professor of History at Lund University, Sweden. He holds MA degrees from Uppsala University in Sweden and San Diego State University in the United States and a PhD from the University of Alberta in Canada. In 2015 the University of Pittsburgh Press published his latest book The Rise and Fall of Belarusian Nationalism, 1906-1931. This is a transcript of the Annual London Lecture on Belarusian Studies delivered on 25 March 2015 at the School of Slavonic and East European Studies, University College London. 
Belarusian nationalism was one of the most recent nationalisms to appear in Europe. Valier Bulhakaŭ in his book Istoriia belorusskogo natsionalizma (2006, 303-304) notes that it emerged between 60 and 80 years after Ukrainian nationalism, another relative latecomer. Thus, if the first Ukrainian language paper appeared in 1848, the first Belarusian one did so only in 1906. Similarly, a complete translation of the Bible appeared in Ukrainian in 1903, while a complete Belarusian translation of the Bible only in 1973.

In general, Belarusian nationalism shows much semblance to the early nationalism of neighbouring Ukraine. While there were some important differences, the overlap is notable. Its southern neighbour can therefore serve as a useful comparison as well as a frame of reference.

Unlike the Belarusians, the Ukrainian ethnographic territory stretched across two polities - the Russian and the Austro-Hungarian Empires. In the considerably more liberal political climate of Austria the Galician Ukrainians were able to organise themselves politically and socially in the second half of the nineteenth century, using the Greek-Catholic Church as an important vehicle for national mobilization. In the Russian empire the Greek Catholic Church was banned in 1839. In addition, Belarusians were divided along religious lines, with roughly $70 \%$ cent being Orthodox and 30\% cent Roman Catholic. An emphasis on religious affiliation therefore risked having the opposite effect of actually highlighting differences within the Belarusian community. Added to this was the further complication that religious hierarchies of both denominations often identified with Polish and Russian traditions, and were indifferent or hostile to Belarusian nationalism.

Belarus was one of the least developed and poorest areas of the European part of the Russian Empire. In the territory which today constitutes the Republic of Belarus, school attendance was $6 \%$ cent. The minority which did attend school was instructed in the Russian, and, to a lesser extent Polish language. The neighbouring ethnic Lithuanian lands had a similarly low level of economic development, but differed from the orthodox Belarusians by a higher level of literacy. They shared these characteristics with Roman Catholic Belarusians, whose higher level of literacy was reflected in the prominence of Roman Catholics among the pioneers of Belarusian nationalism.

Following the crushing of the Polish uprising of 1863, use of the Ukrainian and Belarusian languages were restricted. Add to this the fact that Russia until 1906 was an autocracy which lacked a constitution and a parliamentary system of governance, even a body of popular representation. The first Belarusian political party - the Belarusian Socialist Hramada - was founded in 1902. Following the revolution of 1905 after which the ban on publication in the Belarusian language was lifted, new venues opened up. Particularly important was the appearance of 
the paper Naša Niva (Our Field) in 1906, which came to play an extraordinarily important role in the development of Belarusian national consciousness.

Andrew Wilson refers to the 'false starts' of Belarusian national activism and identifies, in particular, two important precursors to modern, ethnic Belarusian nationalism. The first was the so-called zapadnorusizm, or 'West-Russism,' a concept promoted by the tsarist authorities. This concept envisioned a larger, East Slavic, or Rus' people consisting of three branches: the Great Russians, the Little Russians and the Belarusians. Recognizing the peculiarities of Belarusians and their regional culture as being different from their closely kindred Russians and Ukrainians, it was used by the imperial authorities to counterbalance Polish influences and weaken Polish claims to the historically Lithuanian-Belarusian lands.

Another important movement that appeared a little bit later was the so-called Krajovaja ideology, or krajovasć. This current showed some similarity with zapadnorusizm in the sense that it embraced the multi-ethnic, multilingual cultural legacy heritage of these borderlands. If Zapadnorusist thought grew out of an east Slavic, orthodox tradition, krajoŭcy grew out of a tradition rooted in the Grand Duchy of Lithuania and the Polish-Lithuanian Commonwealth (as opposed to the emerging Lithuanian national movement, which increasingly identified with the geographically smaller, Lithuanian-speaking territories which today roughly make up the nation-state of Lithuania). The traditions of zapadnorusizm and krajovasć both contributed to the development of modern, Belarusian ethnic nationalism.

\section{Naša Niva}

To the early Belarusian nationalists Vilinia, or Vilnius, was the self-evident first choice for a capital. This was the most important centre for Belarusian intellectual activism and the city where Naša Niva was published. Other groups, however, also laid claims to the city. Lithuanian nationalists regarded the city as their capital, its majority Polish population saw the city as Polish. Forty-one per cent of its residents were Jews, and the city played an extraordinarily important role for the Lithuanian Jews - the Litvaks - who referred to their Vilna as the Jerusalem of Eastern Europe. Until 1915 it was, of course located in the Russian Empire. Competing with at least four other groups with overlapping claims is hardly the most beneficial point of departure for an aspiring nationalist movement seeking to establish itself in competition with others. Naša Niva brought together a number of the leading early Belarusian activists, the brothers Luckievič, Anton and Ivan, the most celebrated authors Janka Kupala and Jakub Kolas, and intellectual activists such as Vaclaŭ Lastoŭski, who came to play an important role in the Belarusian People's Republic. 
Naša Niva not only published poetry and essays, but also addressed social, political and religious matters. The largely illiterate local Belarusian peasantry was in 1906 largely unfamiliar with concepts of democracy, nationalism, socialism and modern political mobilization. The aspiring nationalist had to start from scratch: how do you organise society politically? What is a parliament? What is political democracy? These, and other terms needed to be introduced to a peasantry. The pioneers of Belarusian nationalism were more comfortable writing in Russian or Polish - some were even more comfortable writing in Yiddish than in Belarusian. Yet they made a political choice to use the Belarusian language as they regarded it as the identity marker upon which a Belarusian nation ought to be formed.

The articles published in the early volumes of Naša Niva also emphasized the importance of cleanliness, explaining what bacteria was, or how to build primitive facilities to wash hands and maintain rudimentary personal hygiene. The choice of topics reflected the rather primitive socioeconomic conditions in the crowded, simple houses with their dirt floors, where during the winter seasons the living space was often shared with animals, and where the sanitary conditions subsequently were poor. By explaining how bacteria worked, emphasizing the need to wash one's hands, to keep clean to prevent infections and transmit diseases, the activists sought to lay the foundations for an improved life for the Belarusian peasantry. If this is something taken for granted today, it was not taken for granted in Europe before Pasteur, only half a century earlier. Hands-on instructions on how to set up basic sanitary equipment at home became building blocks and the first steps towards building civil society. One problem was that whereas the nationalists had a rather clear idea of whom the Belarusians were, as a rule their intended members of the nation themselves often did not. In the absence of national self-identification they therefore often relied on the views of ethnographic expertise. This was a tradition which started at the turn of the century and continued well into the Soviet period.

One aspect of the ethnographic categorisation of people was to survey their appearance, such as physical characteristics, dresses, dialects, and folklore. What, in the view of the nationalists, made them specifically Belarusian? What were their dress codes? What were the physical attributes and appearance? What did their language sound like? The early 20th century was a period during which nations were racially defined and conceptualized. That also Belarusian nationalists would use racial categories to define and delineate the nation they constructed is therefore unsurprising. We can identify two currents here. On the one hand you have one school which claimed that the Belarusians were slavicized Balts, descendants of the so-called Krievans or Kryvičy, a local people which appears to have been linguistically assimilated into the eastern Slavic population in the ninth century. The belonging of this people is disputed: while some have perceived them as Balts, oth- 


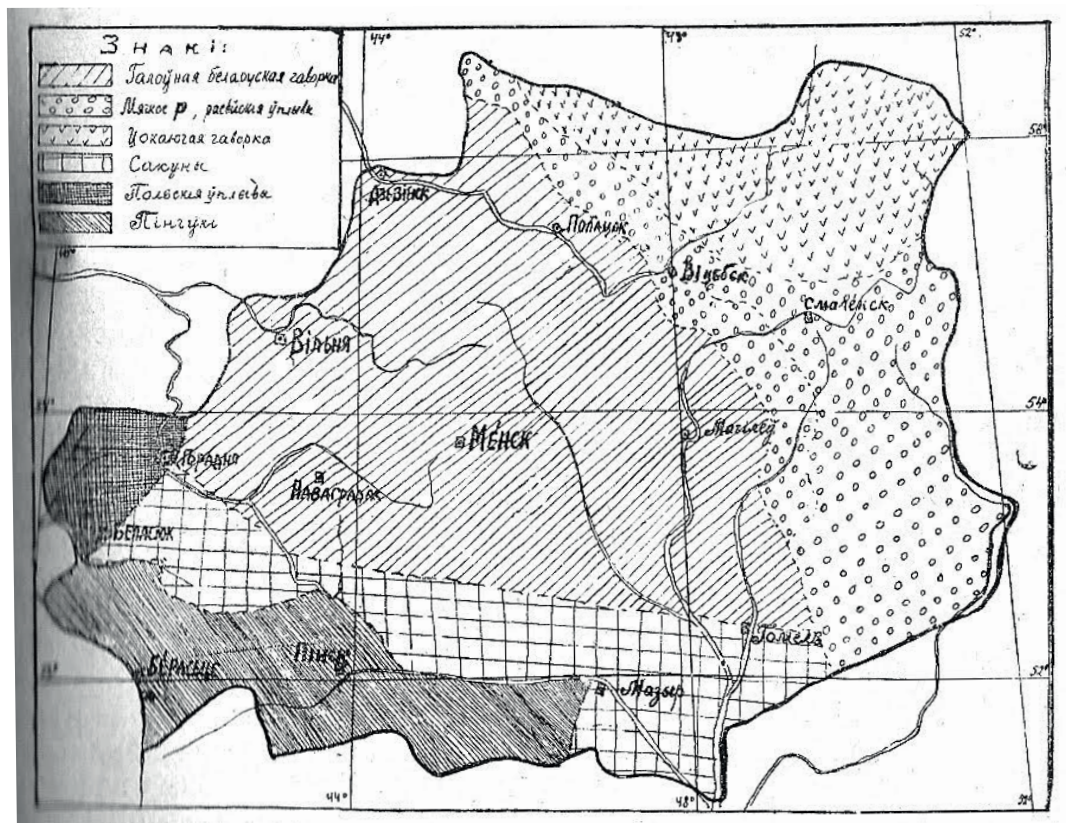

Беларускія гаворкі.

FIGURE 1: Arkadź Smolič was one of the pioneers in documenting the variation of the local dialects. Documentation and classification were important for the national activists' claim to nationhood and territory. Source: Arkadź Smolič, Heohrafija Bielarusi.

Vydannie 3-je, značna pieraroblienaje i pašyranaje (Wilno: Vilienskaje vydaviectva B. A. Kleckina, Bielaruski addziel, 1923), 125.

ers argue they were Slavs - the purest of the Slavs who, unlike the Russians, had escaped the plight of miscegenation with Mongolian and Finnic blood. Cultural and linguistic definitions of nationhood were, however, more commonly invoked.

So who were Belarusians? Many of the nationalist pioneers relied on Professor Jaŭchim Karski's 1903 map of Belarusian dialects, which later came to be perceived as synonymous with the area of settlement of Belarusian people. With the partial exception of the marshlands to the south, Belarus was a landlocked area without any clear natural borders. If in the north-west there was a linguistic boundary with the Baltic languages, while in the west the ethnographic boundary between Roman Catholic Belarusians and Poles was often fluid and anything but self-evident. The eastern boundary between Belarusians and Russians was even less so.

Delineating the boundaries of the nation was a first step in nationalist mobilization, stage A of the nationalists' project of identifying where Belarusians lived. Secondly, they needed to establish a codified language. The Belarusian language 
used in the early years of Naša Niva was inconsistent in grammar, orthography, and vocabulary. Therefore, standardization of vocabulary and grammar and producing dictionaries was necessary for those who sought to establish Belarusian as a language of its own, rather than a dialect of Russian, Polish, or Ukrainian.

Branislaŭ Taraškievič, a very important figure for the development of a Belarusian national consciousness, popularized the Belarusian language by writing a grammar book in 1918, which was published in several editions. Arkadź Smolič's 1919 map of Belarusian dialects specified, in detail, the extent of the Belarusian language and mapped its dialects: zones of Polish, Ukrainian, and Russian influence, but also an imagined Belarusian heartland where the Belarusian language was spoken in its 'purest' form - upon which, the nationalists imagined, the standardized language ought to be based.

Political mobilization was underwritten by the revolution of 1905, following which the restrictions on the use of the Belarusian language were lifted. By 1916 the contours of a movement basing its political claims upon claims about the existence of a separate, Belarusian culture rather perceiving themselves as varieties of Russian or Polish traditions are becoming visible. Many of the early nationalists embraced a non-Marxist form of socialism. The issue of land redistribution was central, as the activists tended to perceive the Belarusian people essentially as an impoverished peasant class, without significant class divisions within. This was, after all, a society which lacked a nobility of its own, as its elites had been Polonized and Russified in the previous centuries. Most of the cities were dominated by Jews while the overwhelmingly rural Belarusians were conceptualized by the adherents of Belarusian nationalism as a classless peasant society. Early nationalism emphasized strongly the need for education and building of economic cooperatives as a basis for achieving social justice. At this point, no one really talked about independence - that was something that appeared later on.

\section{Ober Ost}

A major catalyst for organised Belarusian nationalism followed in the wake of the radical transformations of World War I. Following the defeat of the Russian troops at the battle of Tannenberg in 1914 the German army drove the Russians out of East Prussia and back into the Russian Empire. From 1915 to 1918 the territories which today constitute Poland, the Baltic states and parts of Western Belarus were under German administration.

As they evacuated the territory, the imperial Russian authorities disseminated horrific rumours about the advancing German troops: how they brutally raped 


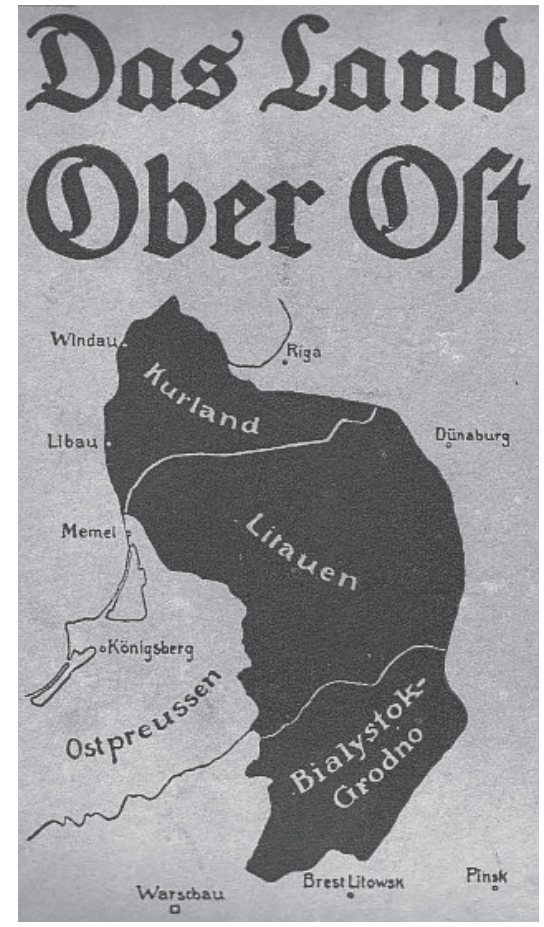

FIGURE 2: The Land Ober Ost under German administration from 1915-1918 included significant Belarusian-speaking territories. Source: Das Land Ober Ost: Deutsche Arbeit in den Verwaltungsgebieten Kurland, Litauen und Białystok-Grodno. Herausgegeben im Aufrage des Oberbefehlshabers Ost, Bearbeitet von der Presseabteilung Ober Ost. Mit 23 Lichtbildern, 3 Karten und 13 Federzeichnungen (Stuttgart and Berlin: Verlag der Presseabteilung Ober Ost, 1917).

women, crucified captive soldiers and bayoneted children. This crude propaganda was similar to that circulated in the yellow press in France and Britain at the time. In the Belarusian lands this triggered panic and as many as 2.2 million people left these borderlands before the Germans arrived. The overwhelming majority of these refugees were Orthodox; Russians and Belarusians. As a result, the eastern boundary of Orthodox Belarusian settlement was pushed back up to $200 \mathrm{~km}$ eastwards as many of the Orthodox inhabitants evacuated the area. Ironically, the arrival of German troops heralded a relatively lenient rule.

The German authorities were quite surprised to encounter a people they had not heard of before; the local population, they soon realized, were neither Lithuanians, nor Poles, nor Russians. The German administrators interchangeably used terms such as Völkerschaft or Völkerstamm, roughly translatable as tribe or ethnicity. From early on, the occupying authorities took an active interest in Belarusian nationalism, which they regarded a potentially useful tool to counteract 
Polish nationalism with which they were familiar, and which regarded as a more substantial obstacle to German control. They established schools and theatres, they printed newspapers and they employed the brothers Ivan and Anton Luckievič to edit and publish a Belarusian language newspaper which got a significant distribution in the German-occupied part of the Belarusian lands. Yet, the fact that many Orthodox locals had left the area meant the pool of intended recipients of the nationalist message had been depleted. In turn, this meant that the nationalists were unable to fully utilize the new political situation and the opportunities it offered. In 1917, in the Belarusian lands under German occupation, 73,000 pupils attended school, many in the Belarusian language.

If this was the situation in the German-occupied territories, referred to as the Land Ober Ost, the lands in the east still under imperial Russian control were quite different. The imperial authorities showed considerably less tolerance towards Belarusian nationalist agitation, and war-time restrictions again brought new, tighter restrictions.

\section{Bolshevik Revolution}

The importance of the Bolshevik revolution in 1917 was a watershed. In the elections to the Constituent Assembly on 12-19 November 1917 the Bolsheviks did very well in the districts, which today encompass the Republic of Belarus. If the Bolsheviks received no more than a quarter of the popular votes in all of Russia, in the districts of Viciebsk, Minsk, and not least, the western front, the Bolsheviks had massive support, receiving up to two-thirds of the votes cast. Belarusian nationalist parties, on the other hand, performed very poorly, gathering but $0.3 \%$ cent of the popular vote.

Of course, many of the Bolshevik votes in the Viciebsk and Minsk guberniias were not cast by local Belarusian peasants, but by war-weary soldiers attracted by the Bolsheviks' promise of 'peace at all costs'. All other political parties had to relate to the Bolshevik seizing of power, and this included the Belarusian nationalists. Belarusian nationalists now felt that this was the time to act and on 5 December 1917, they gathered the so-called All-Belarusian Congress. In nationalist historiography one often encounters the claim that 1,872 Belarusian delegates convened in the Minsk city theatre. Yet, as any visitor to that building can easily testify, that building simply cannot accommodate that many people. The records of its organisers mention more modest estimates of between 300 and 500 people being present. Many of the important activists, not least those in the Land Ober Ost, were unable to attend. The gathered declared their intention to set up a Belarusian state and a Belarusian army, and announced their desire to 


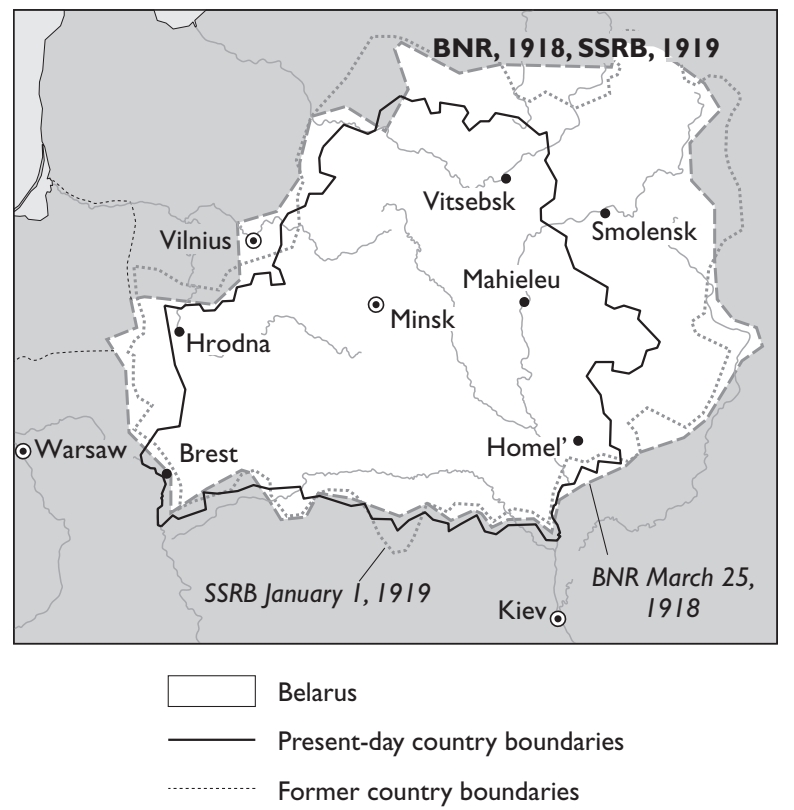

FIGURE 3: BNR, 1918, SSRB, 1919 map. Source: Rudling, Per Anders, 2014. The Rise and Fall of Belarusian Nationalism, 1906-1931. University of Pittsburgh Press.

Reprinted by permission of the University of Pittsburgh Press

establish Belarusian independence. They set up the Rada, or Council, intended as a Belarusian national government. It was not, however, able to operate very long before the Bolsheviks dissolved it on 17 December 1917.

\section{Brest-Litovsk and the BNR}

We are all familiar with the treaties that concluded World War I, not least how these harsh agreements came to radicalise public opinion in the defeated former Central Powers. However, had the Central Powers prevailed in the war, there are few reasons to assume their conditions would have been any less severe. The conditions stipulated in the treaty of Brest-Litovsk between Imperial Germany and the Bolsheviks gives us an idea of what sort of terms could have been expected. In order to conclude a separate peace with Germany, Russia had given up half of its European territory, half of its industries and 80 per cent of its coal mines. The Western boundaries of Russia were pushed back to roughly the borders of Muscovy under Ivan IV. After that the peace treaty was signed on 3 March 1918 and German troops arrived in mid-March. After the Bolsheviks had retreated the Belarusian activists re-convened and on 25 March 1918, exactly 97 years ago today, the Belarusian People's Republic (BNR), - Belaruskaja Narodnaja Respublika - was 
declared over all 'ethnographic Belarusian territories,' from the German border in the west, to Briansk and Viasma in the east, an area over which the activists, of course, had no physical control.

The activists of the BNR were, for the most part, leaning towards Social Revolutionary positions. As the pro-independence parties had received only marginal popular support in the elections to the Constituent Assembly, its support from the people it claimed to represent can indeed be called into question. Their influence on the ground, under the conditions of German occupation, was marginal. Its activities resembled a political association, or a discussion club intensely interested in symbolic and formal legal issues, in particular, designing and establishing official symbols. The BNR Rada declared the white-red-white flag which had been composed one year earlier as the state flag of the BNR, and adopted the Pahonia, 'the chase,' the symbol of the medieval Polish-Lithuanian Commonwealth, as its state coat of arms. A national anthem was composed and nationalist publications increased significantly. The Germans remained committed to the Brest-Litovsk Treaty. They tolerated the national activists and their BNR, but did not allow them to exercise any real influence. The BNR had an army but these groups were anarchic and existed mostly on paper. Money and uniforms donated to them by Poland and the United States were embezzled. The BNR issued passports but lacked recognized international borders as well as border guards to check them. Much of the Rada's activities are best understood as an attempt to demonstrate that a Belarusian people existed, and their preoccupation with symbols of state powers and their dissemination as a way to gain acceptance for this idea in the emerging Mitteleuropa which Erich Ludendorff, the de-facto ruler of Germany, now envisioned. This project included a number of new states, either German satellites or under its protection, including a Polish Kingdom, a Finland with a German price as king, and a hetmanate in Ukraine under Pavlo Skoropads'kyi.

Following the collapse of the Central Powers in November 1918, German troops left Minsk the following month, at which point the Bolsheviks returned. Stalin, the People's Commissar of Nationalities, shared with the Belarusian nationalists the conviction that a Belarusian people and a Belarusian language existed. Many of the leading Bolsheviks did not share this idea, dismissing Belarus as a fiction and a tool of German and Polish imperialism.

\section{Soviet Belarus}

Shortly before the Bolsheviks returned to Belarus following the German retreat, Stalin issued orders from Moscow that a Belarusian Soviet Socialist Republic 
(SSRB) be established. The urgency was so great that the Bolsheviks' declaration of the new republic on 1 January 1919 was carried out in Smolensk, even before the Bolsheviks had reached Minsk, their intended capital of the new Soviet republic. It seems reasonable to assume that the All-Belarusian Congress and the 25 March declaration of the BNR influenced at least sections of the Bolshevik functionaries towards being more open to the idea of Belarusian statehood. One indication of this is the geography of the 'first' SSRB: the borders of the BNR and the 'first' SSRB show a nearly one-to-one geographical overlap.

The Bolsheviks intended for the SSRB to have its own Communist Party, Supreme Soviet, and people's commissariats. Like the Ukrainian SSR and the Russian SFSR, it was technically independent until the foundation of the USSR in 1922. Whatever the original intentions, the plans were soon changed. Already the following month, as the Bolsheviks advanced further and captured Vilnius a new decree stipulated that the SSRB was to merge with the recently declared Lithuanian Soviet Socialist Republic into what was called the Lithuanian-Belarusian SSR, LitBel for short. Like the BNR and the SSRB, LitBel was not to last. As Poland captured Vilnius - which it kept throughout the inter-war period - the capital of LitBel was evacuated to Minsk and, as the Polish forces also captured Minsk in August 1919, LitBel effectively ceased to exist.

What about the BNR? In the summer of 1920, it 'renewed' its existence in exile. The BNR activists soon split into two groups, one reorganised in Kaunas under Lithuanian tutelage, another orientated itself in Poland. A last-minute attempt to convince the delegates at the Versailles peace conference to recognize the state independence of the BNR failed.

\section{Poland Resurgent}

In resurgent Poland, which at this point controlled much of the Belarusian lands, opinions regarding how to organise the new state differed. There were two main rival concepts: one was the so-called federalist solution, promoted by Józef Piłsudski and his followers, who argued for the restoration of the multi-ethnic Polish-Lithuanian Commonwealth. Against this view stood the vision of the socalled National Democrats under Roman Dmowski, who represented an ethnonationalist model of a smaller, but ethnically homogenous, Polish nation state. The issue of the Polish eastern border was not an easy one, as major Polish population centres, such as Wilno and Lwów, were located east of the so-called Curzon line proposed by the British at Versailles.

The situation on the battlefield determined many of the decisions. Piłsudski told his commanders that 'history would not forgive us' if they did not use this 
chance to take control over the Wilno area. Himself a Pole from Wilno, Piłsudski regarded a city to be a natural, integral part of a restored Polish state. As the Bolsheviks were tied up in the civil war against the White forces, Piłsudski's forces were able to march further east and to capture both Minsk and Kyiv. By the summer of 1919 the federalist vision of a Poland od morza do morza - a Polish state from the Baltic to the Black Seas - suddenly did not appear all that unrealistic. Polish forces held these territories for almost a year. After the Bolsheviks prevailed in the civil war, the Red Army under Mikhail Tukhachevskii's command launched a large counter-offensive in July 1920, pushing the Polish forces all the way back to Warsaw.

As the Bolsheviks stood outside Warsaw, the Bolsheviks declared the reestablishment of the SSRB on 31 July 1920. After the battle of Warsaw, which halted the Bolshevik advance, peace negotiations started in Minsk on 17 August. An armistice was reached on 20 October and a final peace treaty signed in Riga on 20 March 1921. It is telling that even though the negotiations took place in Minsk, there were no delegates representing the recently re-established SSRB taking part in the negotiations.

The boundaries agreed upon in Riga satisfied none of the parties. Poland's eastern boundaries were neither what the federalists nor the national democrats had hoped for. Inter-war Poland increasingly regarded itself as a Polish nation state, even though it was a multi-ethnic state with very significant national minorities. To Ukrainian and Belarusian nationalists the treaty was a disaster, confirming not only the defeat of their projects, but leaving these ethnic groups divided by an increasingly fortified border between two hostile states. The Lithuanians, who in Versailles had been promised Vilnius as their capital, blankly refused to accept the new borders and broke off all contacts with Poland, specifying in their constitution Vilnius' status as their 'eternal capital'. In the following years, they invested significant efforts in fomenting unrest in Poland in the hope that they would one day be able to regain the city. Until 1924, the Kaunas government supported a low-intensity partisan insurgency in parts of Western Belarus, enthusiastically supported by a Soviet leadership which, at least for the time being, had no other choice but to reluctantly accept the Riga borders. As anyone familiar with modern European history knows, it did not, however, regard them as final.

\section{Legacies of Belarusian Statehood}

While Belarusian nationalism was still in its infancy in the eventful fifteen years from the appearance of the first Belarusian paper until to the treaty of Riga, this was also a period of remarkable growth of Belarusian national consciousness and 
activism. Belarusian nationalism remained a marginal and contested phenomenon with limited popular following within a overwhelmingly rural and illiterate population with vague ideas of concepts such as nations, nationalism, popular sovereignty and political organisation. Belarusian nationalism, albeit in its infancy, was sufficiently interesting as a political factor to attract the interest of a number of parties which, at one point or another, had political interests in the region. Much like conflict between Germany and Russia in World War I, the political rivalry between Soviet Russia, Poland, and Lithuania offered ample political opportunities for Belarusian national activists who for much of the 1920s strengthened their positions on both sides of the 1921 Riga border.

Even though neither the BNR nor the BSSR in their various incarnations can be regarded as states in the Weberian sense, as a community with 'a monopoly of legitimate use of force within a given territory', both can be characterized in terms of proto-states, the existence of which helped build legitimacy for the notion of Belarusian statehood. Belarus is unique in Europe in that it has two rivalling modern foundation myths. The Soviet legacy arguably looms stronger in Belarus than in any other former Soviet republic, the current government relying heavily on Soviet references to shore up its legitimacy. At the same time, Belarus remains the only country in Europe with a government in exile, which regards itself as the successor of the BNR. Both groups invoke mutually exclusive narrations of the past.

The events of 1918 have become the subject of intense myth-making. They are filled with content and meaning, with the result that they today have taken up a life of their own. It is safe to say that much of the meaning invested in these symbolic events today has relatively little to do with the realities and actual conditions back then. As such, the importance of 25 March 1918, has arguably grown and is paradoxically of greater importance today, in 2015, than it was 97 years ago. 